\title{
Kurumsal İletişimde Kurumsal Dergilerin Kullanımı Üzerine Bir İnceleme
}

\author{
DOI: 10.26466/opus.885254 \\ * \\ Sevim Koçer * - Neslihan Ölçer ** \\ * Doç Dr., Kocaeli Üniversitesi, İletişim Fakültesi, Kocaeli/Türkiye \\ E-Posta: sevimkocer2004@yahoo.com ORCID: 0000-0003-1813-5491 \\ ** Dr. Kocaeli Üniversitesi, Kocaeli/Türkiye \\ E-Posta: nolcer@hotmail.com ORCID: $\quad$ 0000-0002-1376-1189
}

Öz

Kurumsal dergiler; eğitmek, bilgilendirmek, çalışanlarla ve dış paydaşlarla iletişim kurmak amactyla çıkarılırlar. Online olarak çıkarılan kurumsal dergiler video haber içerikleri ve yüksek kaliteleriyle önemli kurumsal iletişim araçlarıdır. Bu çalışmada online yayınlanan Tüpraş'ın Rafine Dergisi ve Opet'in Kilometre Dergisi kurumsal iletişim açısından incelenmiştir. Bu çalışma kurumsal iletişim sürecinde online yayınlanan kurumsal dergilerin rolünü ortaya koyması bakımından özgün bir çalı̧̧madır. Araştırmada online olarak çıkarılan dergiler içerik analizi yöntemiyle incelenmiştir. Kurumsal dergiler, kurumsal iletişimin taraflar ve araçlar ile kurumsal iletişim uygulamalar olan kurumsal kimlik, kurumsal davranış, kurumsal imaj, kurumsal vatandaşlık, kurumsal itibar ve kurum kültürü unsurlar açısından analiz edilmiştir. Dergiler toplam 101 puan üzerinden değerlendirilmişstir. Rafine Dergisi toplamda 91 puan alırken; Kilometre Dergisi 87 puan almıştır. Rafine Dergisi; kurumsal davranı̧, kurumsal vatandaşlık ve kurumsal itibar boyutlarında tam puan alırken; Kilometre Dergisi kurum kimliği unsurlarına yer vermede daha yüksek puan almıştır. Kurumsal dergiler incelenen örneklem ve kriterler açısından kurumsal iletişim uygulamalarına büyük ölçüde yer vermektedir.

Anahtar Kelimeler: Kurumsal iletişim, kurumsal dergi, Rafine, Kilometre. 
ISSN:2528-9527

E-ISSN: 2528-9535

YIl Year: 11

Cilt Volume: 18

Sayı Issue: Yönetim ve Organizasyon Özel Sayısı

Temmuz July 2021

Uluslararası Toplum Araştırmaları Dergisi

International Journal of Society Researches

Makalenin Geliş Tarihi Received Date: 23/02/2021

Makalenin Kabul Tarihi Accepted Date: 07/04/2021

\title{
An Investigation on the Use of Corporate Journals in Corporate Communication
}

\begin{abstract}
Corporate journals; they are issued to educate, inform and communicate with employees and external stakeholders. Corporate magazines published online are important corporate communication tools with video news and high quality. In this study, Tüpraş's Rafine Magazine and Opet's Kilometre Magazine, which are published online, have been examined in terms of corporate communication. This study is an original study in that it reveals the role of corporate journals in corporate communication. In the research, these journals published online were analyzed by content analysis method. Corporate magazines have been analyzed in terms of parties and tools of corporate communication and corporate communication practices such as corporate identity, corporate behavior, corporate image, corporate citizenship, corporate reputation and corporate culture. Journals were rated on a total of 101 points. While Rafine Magazine got 91 points in total; Kilometre Magazine got 87 points. Rafine Magazine; while getting full points in corporate behavior, corporate citizenship and corporate reputation dimensions; Kilometre Magazine got higher scores in including corporate identity elements. Corporate magazines largely cover corporate communication practices in terms of the sample and criteria examined.
\end{abstract}

Keywords: Corporate communication, corporate magazine, Rafine, Kilometre 


\section{Giriş}

Yönetim dünyasında, herhangi bir şirketin geleceğinin; hissedarlar ve yatırımcılar, müşteriler ve tüketiciler, çalışanlar ve şirketin içinde bulunduğu toplum üyeleri gibi kilit paydaşlar tarafından nasıl görüldügüne bağlı olduğuna dair yaygın bir inanç vardır. Kurumsal iletişim temelde şirketler tarafından stratejik ve araçsal olarak kullanılan bir yönetim işlevidir (Cornelissen, 2004, s.9).

İşletmelerde iletişimin rolü değişmiştir. İletişim örgütün sağllğ iç̧in daha karmaşık, stratejik ve hayati önemdedir. Bu da kurumiçi, kurumdış1 veya ticari veya gönüllü takipçilerine göndereceği mesajlara bağlıdır (Goodman, 2004, s.203).

Başarılı olmak için kuruluşların paydaşlarıyla sağlıklı etkileşimli ilişkiler geliştirmesi, sürdürmesi gerekir ve bir şirketin iletişim sisteminin amacı bu etkileşimi kolaylaştırmaktır. Kurumsal iletişim için bir sistem oluşturmak bu nedenle her şirketin strateji belirleme ve yürütmesinin hayati bir bileşenidir (Van Riel ve Fombrun, 2007, s.9).

Kurumsal iletişim, işletmenin rekabet avantajı kazanmasını sağlayan stratejik bir araçtır. İşletme bu aracı; çalışanlarını ve toplumu yönlendirme, motive etme, ikna etme ve bilgilendirme için kullanır. Günümüzde çalışanlar, müşteriler, yatırımcılar, tedarikçiler ve genel olarak toplum firmadan faaliyetleri ile ilgili doğru bilgi ve yüksek düzeyde iletişim kurmasını beklemektedir. Firma içindeki bir iletişim takımı; örgüt imaj ve kültürünü geliştirmek için politikalar ve klavuz hazırlamalı; tutarlı mesajlar hazırlamalı ve kriz anlarında olduğu gibi rutin zamanlarda da halkla iletişim kurmalıdır (Goodman, 2004, s.201).

Kurumsal dergiler kurumsal iletişim kurmada etkili araçlardır. Kurumsal dergiler; kaliteli görselleriyle, kurumdan haberlere, sektördeki son gelişmelere, kurum içinde yaşanan gelişmelere ve kurumların yaptıkları etkinliklere yer vermesi açısından paydaşlarıyla kuracağı iletişimde önemli bir role sahiptir. Günümüzde sektörde lider konumda olan büyük işletmeler kurumsal iletişimde kurumsal dergilere önem vermektedir.

İşletmeler kurumsal web sayfalarında online olarak kurumsal dergilerini yayınlamaktadır. Baskı maliyeti ve sınırlı içerikten kurtaran bu uygulama ile kurumsal dergiler periyodik olarak hazırlanabildiği gibi 
online hazırlanmanın bazı avantajlarına da sahiptir. Baskı maliyeti olmaması bir yana, video haber bulundurma, sayfa sinırından kurtulma, görsellerin daha net olması gibi avantajlar kurumsal dergilerin sayısının artmasını sağlamıştır.

$\mathrm{Bu}$ çalışmada sektöründe lider konumda olan Tüpraş'ın online kurumsal iletişim dergisi olan Rafine Dergisi ve Opet'in Kilometre dergisi kurumsal iletişim açısından incelenmiştir. Dergilerin 2020 yılında çıkardıkları son sayıları içerik analizi yöntemiyle analiz edilmiştir.

\section{Literatür}

\section{Kurumsal İletişim}

Bu bölümde kurumsal iletişim kavramının tanımı, araç ve ortamları ve kurumsal iletişim uygulamaları incelenmektedir.

Kurumsal İletişimin Tanımı: Bir örgütün iletişim sistemi, paydaşlarıyla iletişim kurmada kullandığı çoklu taktik ve stratejik medya ve bu medya aracılığıyla yaymayı seçtiği mesaj içeriği olarak tanımlanabilir. Bu iletişim sistemi; pazarlama iletişimi, halkla ilişkiler, yatırımc ilişkileri ve çalışan iletişimlerini kapsar; ayrıca, bir organizasyonun, faaliyetleri nedeniyle etkilemek istediği kamuoyunu da içerir (Van Riel ve Fombrun, 2007, s.2).

Kurumsal iletişim, yönetimsel bir işlev olarak bilinçli kullanılan tüm iç ve diş iletişim biçimlerinin yer aldığı ve şirketin bağımlı bulunduğu gruplarla ilişkilerinde etkili ve verimli bir şekilde birleştirildiği bir yönetim aracıdır (Cornelissen vd. 2006, s.116).

Kurumsal iletişim, örgütün içsel ve dişsal iletişimi ile ilgili bir yönetim işlevi olarak tanımlanır. Kurumsal iletişim, halkla ilişkiler, yatırımcı ilişkileri, çalışanla ilişkiler, toplumsal ilişkiler, devletle ilişkiler, teknik iletişim, eğitim ve işçi geliştirme, pazarlama iletişimi ve yönetim iletişimi alanlarını içermektedir. Pek çok örgüt kurumsal iletişimin birer işlevi olarak; sponsorluk etkinlikleri, kriz iletişimi ve reklam işlevlerini dahil etmektedir (Goodman, 2004, s.200).

Kurumsal iletişim dört temel bileşenden oluşur. Bunlar; organizasyon hakkında mesaj iletilmesi, iletişim için uygun ortamların (dergiler, televizyon, resimler, kurumsal hediyeler, intranet vb.) kullanılması, 
paydaşlara bilgi yayılması ve iletişim yoluyla şirketin imajını veya itibarının arttırılmaya çalışılmasıdır (Ormino, 2007'den aktaran Sinha ve Bhatia, 2016, s.120). Balmer ve Greyser (2006) yeni kurumsal iletişim sürecinde, kurumsal mesajların iletilmesi için reklam, yeni medya, doğrudan pazarlama ve sponsorluklar gibi farklı iletişim kanallarının her bir paydaş grubuyla eşleştirilmesini vurgulamaktadır.

Kurumsal iletişim uygulamasında çeşitli taktik ve teknikler kullanılır. $\mathrm{Bu}$ süreçte kurumlar iletişimde kullanacakları paydaşlarla toplu veya bireysel olarak dağıtılacak mesajların türü; monolog ve diyalog iletişim, kanal seçimi, konuşmacılar, zamanlama, mekan ve etkileşim forumları konusunda seçim yapmalıdır. Bu tür seçimler mutlaka mesaj, ortam, paydaşlar arasındaki tahmine dayalı ilişkilerin anlaşılmasına ve stratejik kurumsal iletişimin etkisine bağlı olmalıdır (Sinha ve Bhatia, 2016, s.122).

Kurumsal İletişim Uygulamaları: Kurumsal iletişim bir stratejik yönetim işlevidir. İçinde pek çok iletişim uzmanı uygulayıcı olarak rol almaktadır. Büyük bir firmada kurumsal yönetimde rol alan iletişim uygulayıcıları çeşitli konularda sorumluluk alırlar. Bu sorumluluk alanları; reklamcılık, tanıtım, toplum ilişkileri, kurumsal reklamcllık, kriz iletişimi, iç iletişim, hükümet ilişkileri, finansal iletişim ve yatırımcı ilişkileri, medya ilişkileri, konu yönetimi, lobicilik, promosyonlar, sponsorluk ve halkla ilişkiler olarak sıralanabilir (Cornelissen, Van Bekkum, ve Van Ruler, 2006, s.117).

İletişim uygulayıcıları; iletişim materyalleri yazma, dilbilgisi ve yazım için düzenleme ve yeniden yazma, iletişim kampanyalarının teknik yönlerini ele alma, broşür hazırlama, fotoğraf ve grafik yapma ve medya bağlantılarını kullanma gibi faaliyetlere odaklandıklarında teknisyen olarak nitelendirilir. İletişim teknisyenleri, başkalarının aldığı kararları uygularken karar alma süreçlerine dahil edilmezler (Cornelissen vd. 2006, s.119).

Stratejik kurumsal iletişimde beş uzmanlık alanı vardır. Bunlar; intranet yoluyla yapılan iç iletişim, kurum günlüğü ve kurumsal sunumlar; basılı ve görsel-işitsel materyaller, fuarlar, reklam ajanslarının bilgilendirilmesi, medya, sponsorluk ve fon toplama gibi pazarlama iletişimi; basın bültenleri, web yayınları, basın toplantıları, analistlerle gayri resmi görüşmeler ve standart kurumsal sunumlar içeren yatırımcı ilişkileri; devletle gayri resmi görüşmeler, CEO konuşmaları, üst yönetim 
danışmanlığı ve araştırma gibi kamu işleri yönetimi; paydaşlarla görüşmeler, basın ilişkileri ve basını izleme sorunları gibi konu yönetimidir (Van Riel ve Fombrun, 2007).

Kurumsal iletişimin diğer bir kritik yönü kilit paydaşların önceliklendirilmesidir. Bunlar devlet, tedarikçiler, ticaret birlikleri, çalışanlar, yatırımcılar, siyasi gruplar, müşteriler ve topluluklar olarak kategorize edilebilir (Van Riel ve Fombrun, 2007; Christensen, Furat, ve Cornelissen, 2009). Paydaşlar kuruluşla ilgili olmaları bakımından birincil ve ikincil olup, çalışanlar, müşteriler, hissedarlar ve topluluklar eski kategoriyi oluştururken, medya, tedarikçiler, devlet, alacaklılar sonradan eklenenler kategorisini oluşturmaktadır (Argenti, 2007'den aktaran Sinha ve Bhatia, 2016, s.123).

Kurumsal iletişim, bir yandan pazarlama ve ürün iletişimi ile uğraşırken diğer yandan yatırımcı, çalışan, medya, toplum ve hükümet ilişkilerini yönetmek için karmaşık bir dizi etkinlik içerir. İç iletişim, özel etkinlikler, yıllık raporlama, marka ve sayı reklamcılığı, kurumsal markalaşma, halkla ilişkiler, krizler ve acil durum iletişimi, kurumsal vatandaşlık ve itibar veya imaj oluşturma da kurumsal iletişimin önemli bileşenleridir (Sinha ve Bhatia, 2016, s.122).

Kurum Kimliği: Kurum kimliği, bir kurumun kişiliğinin anlatıldığı yolların tümünü ifade eder. Kurum kimliği; logolar, renk, yazı tipi vb. tasarım unsurları gibi somut unsurları ve kurumsal davranış, kültür, değerler, misyon, vizyon ve iletişim biçimi gibi soyut unsurları da kapsamaktadır (Wood, 2001, s.95). Kurum kimliği başlangıçta logolar ve görsel tasarımın diğer unsurlar ile sınırlandırılırken zamanla iletişim ve pazarın dışa dönük davranışlarının her biçimini kapsamıştır. Son yıllarda, kurum kimliğine sadece kurumun görülebilen dışsal sunumu değil, aynı zamanda şirkete özgüllüğünü veren istikrar ve tutarlılık gibi öz nitelikleri de dahil edilmiştir (Cornelissen, Haslam, ve Balmer, 2007, s. 7).

Kurumsal Imaj: Kurumsal imaj, paydaşların şirkete yönelik izlenimidir (Vivilaite ve Daubaraite, 2011, s.536). Kurumsal imaj; kurumsal kimliğin, kurumsal iletişim araçları ile girdiği etkileşim sonucunda hedef kitle üzerinde kurum hakkında oluşan izlenimdir (Gemlik ve Sığrı, 2007, s.270). Kurumsal imaj oluştururken, mevcut ve potansiyel tüketiciler arasında 
şirkete karşı olumlu tutum oluşturmak en önemli hedeftir. Kurumsal imaj sürekli gözden geçirilmeli ve kamuoyu, inanç ve değerlerine göre güncellenmelidir. İyi imaja sahip bir firma değişebilen, yenilikçi, açık ve pazarlarında istisnai bir şirket olarak görülmelidir (Vivilaite ve Daubaraite, 2011, s.536).

Kurum imajının, fonksiyonel bileşenleri ölçülebilen somut unsurlarla ilgilidir. Bu unsurlar; yeni isim, logo ve sembollerdir. Duygusal bileşenler ise daha çok psikolojik boyutlarla ilgilidir. Kurum imaj1; kurumun ismi, mimarisi, mal/hizmet çesitleri, geleneği, felsefesi gibi fiziksel ve davranışsal unsurlarını kapsamaktadır (Gemlik ve Sığrı, 2007, s.270). Flavia ve arkadaşları bankaların kurumsal imajları ile ilgili makalelerinde hizmette kolaylık, sunulan hizmetler, kişisel iletişim ve itibar gibi unsurları ölçmüşlerdir (Flavian, Torres, ve Guinalıu, 2004). Uluçay (2018), üniversitelerin imaj ölçümünü yaptığı makalesinde iç paydaşlar ve diş paydaşlara yönelik unsurları ölçmüştür. Her iki paydaş grubuna yönelik olarak imaj ölçümünde çalışanlar, yönetim kalitesi, sosyal sorumluluk, çalışma ortamı, ürün hizmet kalitesi ve iletişim faaliyetleri unsurları incelenmiştir.

Kurumsal İtibar: Kurumsal itibar; işletme çevresinin, işletmeye ilişkin fikirlerinin, varsayımlarının bir toplamıdır. Kurumsal itibar kavramı, işletmenin çalışanlarının, müşterilerinin, yatırımcıların ve toplumun genelinin işletmenin ismine ilişkin oluşturdukları iyi veya kötü, zayıf veya güçlü gibi net duygusal tepkilerini ifade etmektedir (Fombrun,1996, s.37). Oliver, kurumsal itibar ölçümünde bir endeks kullanmıştır. Buna göre bir kurumun itibarının ölçümünde etik yönetim, finansal performans, ürün ve hizmetler, vizyoner liderlik ve iş çevresi altboyutları ölçülmektedir (Oliver, 2010, s.78).

Finansal performans; bir kurumun kârlılık ve yatırım amacıyla risk alabilme ve rekabet edebilme yeteneğini açıklar. Kaliteli iş ortamı; çalışanlar açısından düzen ve temizlik, iyi aydınlatma ve ssıtma, yeterli araç gerecin sağlanması, dinlenme sürelerinin yeterli olması gibi unsurlarla verimli bir iş ortamını ifade eder. Kaliteli ürün unsuru, müşteri beklentisini karşılayacak ürün özelliklerini kapsamaktadır. Duygusal alg1 endeksi; kurumun kamuoyu üzerinde yarattığı olumlu etkiler, alg1 ve çağrışımları içermektedir. Kurumsal liderlik, yöneticilerin çalışanların 
desteğini alarak kurumsal itibarını güçlendirmesi ve hedeflerini gerçekleştirmesidir. Kurumsal vizyonerlik endeksi, kurumun net bir vizyonunun olması ve kurumun bu vizyona uygun hareket etmesi anlamına gelir. Yönetici itibarı endeksi; kurum çalışanlarının yönetici kararlarına güvenmesi, alınan kararların yerinde olduğuna inanması durumunu ifade etmektedir (Oliver, 2010, s.78; Fombrun,1996, s.37; Akım, 2015, s.7-8). Araştırmacılar, kurumsal itibarın sadece firmanın kurumsal iletişim faaliyetlerine bağlı olmadığını, aynı zamanda güven, etik davranış ve farklı paydaşlarla ilişkilerin kalitesi gibi diğer değişkenlere de bağlı olduğunu bulmuşlardır (Sinha ve Bhatia, 2016, s.123).

Kurumsal Vatandaşlık: Kurumsal vatandaşlık, bir şirketin toplum üzerindeki etkilerini ve toplumla olan ilişkilerini yönetmesi olarak tanımlanır. Şirketler, gerçekte faaliyet gösterdikleri bölgelerin vatandaşları olarak hakları ve görevleri olan tüzel kişiliklerdir. Bu haklar ve görevler, geleneksel olarak belirli asgari yasal gerekliliklere ve yasama alanına göre eyalet, ulus veya bölgesel birliğe göre değişen sosyal olarak belirlenmiş ek davranış normlarına tabidir. Kurumsal vatandaşlık, temelde bir işi iyi yürütmek, yasalara uymak, vergileri ödemek ve diğer sorumlu vatandaşlar gibi iyi bir komşu olmakla ilgilidir (Marsden, 2000, s.11).

Kurumsal vatandaşlık bir şirketin temel iş eylemleri, sosyal yatırımları, hayırseverlik programları ve kamu politikalarına katılımı aracılığıyla topluma yaptığı katkılardır. Bir şirketin, hissedarlar, çalışanlar, müşteriler, iş ortakları, devlet organları, sivil toplum kuruluşları ve yerel topluluklar gibi paydaşlarıyla olan ekonomik, sosyal ve çevresel ilişkilerini yönetme davranışıdır (Gardberg ve Fombrun, 2006, s.329).

Kurumsal vatandaşlık davranışını belirleyen sorumluluk boyutları; ekonomik, yasal, etik ve gönüllü olmak üzere dört başlık altında toplanmıştır. Ekonomik sorumluluk; şirketlerin tüketici ihtiyaçlarını karşılayacak üretkenlikte ve kazançlı olmalarını gerektirir. Yasal sorumluluk, şirketlerin yasal bir çerçevede, kanunlara uygun şekilde çalışmalarını gerektirir. Etik sorumluluk, şirketlerin toplumsal olarak kabul görmüş, yerleşik ahlaki standartlara uymalarını gerektirir. Gönüllü sorumluluk; şirketlerin iş yaptıkları çevredeki yerel toplulukların iyileştirilmesi, halka yardım edilmesi gibi çeşitli gönüllü sosyal faaliyetleri 
üstlenmesini gerektirir (Lindgreen ve Swaen, 2005, s.352). İyi bir kurumsal vatandaş; sağlık hizmeti, parklar oyun alanları, binaların restorasyonu köprü ya da tramway yapımı gibi konularda etkinlikler yapmalıdır. İyi bir firma çalışanlarını konferanslara veya bilimsel etkinliklere katılması konusunda teşvik etmelidir (Goodman, 2004, s.206).

Kurum Kültürü: Kurum kültürü; örgüt üyelerinin düşünce ve davranışlarını şekillendiren hakim değerler ve inançlardır (Dinçer, 2013, s.334). Örgütü bir arada tutan, birleştirip bütünleştiren ve diğerlerinden ayırt eden özellikler dizisi olarak kurum kültürü; ortak kabul edilen amaçlar, inançlar ve değerler sisteminin bütünüdür (Barutçugil, 2013, s.450).

Schein (1992) kurum kültürünün unsurlarını soyut ve somut unsurlar olmak üzere iki grupta incelemiştir. Kurum kültürünün soyut unsurları değerler, normlar, inançlar ve varsayımlardır. Kurum kültürünün somut unsurları arasında; çalışanların davranışları, törenler, sloganlar, adetler, hikayeler, mitler, semboller, dil ve kahramanlar sayılabilir.

Toplum Iliş̧kileri: Kurumun dışardaki topluma yardım etmeye yönelik yaptı̆̆ı, sponsorluk, bank koyma, telefon kulübesi yapma, park yapma, okul veya üniversitelere yönelik eğitim programları, yetişkinlere yönelik ilkyardım eğitimleri, su güvenliği, suç önleme ve geri dönüşüme yönelik çabalarını kapsar. Kurum yöneticilerinin okullarda kariyer hakkında konuşma yapma, kan bağışı, yerel okulların ekipman ihtiyaçlarını giderme, yerel felaketlerde şirketlerin ekipman, yiyecek, giyecek ve medikal ihtiyaçlarını sağlamada gönüllü olma gibi toplumsal ilişkilere katkı sağlayan uygulamalarıdır (Goodman, 2004, s.211).

Devletle İlişkiler: Kurumların devletle ilişkisinde; kurumun faaliyet gösterdiği alandaki merkezi, yerel ve yabancı devletler ve ajanslarla ilişkisi kastedilmektedir. Firmaların yasal yükümlülüklere uyması, vergi, borçlar, ticaret ve iş hukukuna uygun davranması, devlet projelerine ayni veya parasal destek vermesi, istiham yaratması, lobi çalışmalarında bulunması firmaların devletle olan ilişkilerine örnek olarak verilebilir. Firmalar, özellikle faaliyet bölgesinde devletin yatırımlarında yetersiz kaldığı temiz su temini, çevre temizliği, çevrenin ağaçlandırılması, eğitim 
ve sağlık hizmetleri gibi alanlardaki eksiklikleri kurumsal sosyal sorumluluk projeleriyle tamamlamalıdır.

Medya İlişkileri: Firmalar kamu ile olan ilişkilerinde medyayı aracı olarak kullanır. Medya ile iyi ilişkileri olan firmalar kamuda iyi bir imaj ve itibara sahip olmada kolaylıklar yaşayacaktır. Firmalar yaptığı etkinliklerin duyurulması, kriz durumunda kamu ile şeffaf iletişimin sağlanması, ürün ve hizmetlerinin tanitılması konularında medyaya ihtiyaç duyar. Bu nedenle firmalar, medya çalışanları ile iyi iletişim kurmalı, medyanın haber yapma süreçlerine hakim olarak ihtiyaç duyduğu bilgileri doğru zamanda ve tam olarak sağlamalıdır. Basın toplantıları, basın gezileri ve basın kokteyllerinde basın mensupları ile tanışılarak iyi ilişkiler geliştirilmelidir. Firma yetkilisi yaptığı bir etkinlik öncesi ve sonrasında basın mensuplarına basın bülteni gönderdikten sonra telefonla aramalı ve basın bülteninin haberleşmesini sağlamalıdır.

Yatırımcı İlişkileri: Yatırımcılarla ilişki inşa etmek firma için merkezi önemdedir, dürüstlük ve netlik gerektirir. Sadece iyi bir pratik yeterli olmaz; pazar alanındaki materyal bilgisi adil açıklanmalı ve yasaya uygun olmalıdır. Yatırımcılar, analistler ve paydaşlarla iletişim firmanın yararınadır. Firmanın güçlü pozitif bir ilişki geliştirmesi için samimi, doğru, tam ve eşzamanlı bilgilendirmeye ihtiyaç vardır. Firma yatırımcılarına bilgi sağlayarak analizlerin sonuçlandırılması ve doğru öngörüler yapılmasını sağlar (Goodman, 2004, s.213-214).

\section{Kurumsal İletişim Aracı Olarak Kurumsal Dergiler}

Kurumsal iletişimde kullanılan pek çok araç vardır. Bunlar arasında kurumların kurumsal web sayfaları, aylık ve yıllık faaliyet raporları, kurum içi iletişim ağları olan intranet, kurum e-postaları, kurumun sosyal medya sayfaları, kurum panoları, basın bültenleri, amblemi, sloganı, iş giysileri, araç ve bina giydirme, kurum bayrak ve flamaları, tabelalar, antetli kağıtlar, ürün ambalajları, reklamlar, kurum içi yazışmalar, yönetici konuşmaları, tanıtım filmleri, kurumsal dergiler vb. sayılabilir.

Dergi; en az haftada bir, en fazla üç ayda bir çıkacak şekilde düzenli bir yayın aralığına sahip, içerisinde metinler barındıran, okurları tarafından 
parayla satın alınan veya talep edilen, ciltli olarak dağıtılan süreli yayındır. Dergiler; tüketici dergileri, kurum dergileri, sektör dergileri, bilimsel dergiler ve marjinal dergiler olarak beşe ayrılır (Gönenç, 2006, s. 8- 9). Kurum dergileri; kurum içi ve kurum dışı olarak ikiye ayrılır. Kurum içi dergiler; eğitmek, bilgilendirmek, çalışanlarla iletişim kurmak, verimliliği ve motivasyonu artırmak amacıyla çıkarılırken, kurum dışı dergiler ise, hizmet, fikir veya ürünü satmak ve ilgili kurumun prestijini yükseltmek amacıyla çıkarılmaktadır (Gönenç, 2006, s.10).

Kurumsal dergiler kurum hakkındaki bilgileri, gerçekleştirilen eylemleri ve etkinlikleri hedef kitleye iletmek için kullanılan yazılı ve görsel unsurları barındıran bir iletişim aracıdır. Kurumsal dergiler, kurumları tüm iç ve dış hedef kitlelerine doğru şekilde anlatabilmeyi ve kurumsal kimliği desteklemeyi amaçlamaktadır (Toku, 2020, s.17).

Dergilerin iç ve dış hedef kitleleri vardır. İç hedef kitle için kurum kültürü ve kurum davranışı; dış hedef kitlede ise daha çok kurumsal iletişim ve kurumsal tasarım ön plana çıkartılır (Korkmaz, 2007, s.386).

Süreli kurumsal dergiler; genellikle yönetici görüşlerine, yapılan etkinliklere, faaliyette bulunulan sektöre dair konulara, çalışanlarının başarılarına, aldıkları ödüllere, yaptıkları sponsorluk ve sosyal sorumluluk projelerine ve firmanın ürün ve hizmetlerine yer verirler.

Haberin veriliş şekli, insanların ilgisini çekecek şekilde sunumu, sayfa düzenleri her derginin izlediği yayın politikasına göre farklıdır. Dergide kuruluşun logosu, künyesi, iletişim adres ve telefonları mutlaka bulunmalıdır. $\mathrm{Bu}$ yayınlar, kurum içinde bir bütünleşme ve kurum dışında da olumlu bir imaja sahip olmak için bir aracı konumundadır (Korkmaz, 2007, s.386).

Günümüzde kurumlar; maliyetten ve zamandan tasarruf etmek amacıyla dijital ortamda yayınladıkları ve kurumsal web sitelerinde yer verdikleri kurumsal dergiler çıkarmaktadır. Bu tür dijital dergiler basılı dergilere göre daha çok avantaj barındırır. Dijital ortamda sayfa sayısı daha çok, görsel unsurlar daha kalitelidir. Dijital dergilerde basılı dergilerden farklı olarak video haberler, video görüşmelerin yer aldığı sayfalar bulunmaktadır. Ayrıca bu dergilere kurum web sayfasından herhangi bir ücret ödenmeksizin erişmek mümkün olmaktadır. Dijital dergiler de basılı dergiler gibi belirli periyotlarda çıarken, içeriğin 
güncellenmesi daha kolaydır ve kalıcı olmaları bakımından arşivleme işlevi de görmektedir.

\section{Araştırmada İncelenen Dergiler Hakkında}

Tüpraş tarafından çıkarılan Rafine dergisi 2007 yılında yayın hayatına başlamış; altı ayda bir yayımlanan kurumsal iç iletişim organı olarak çıkarılan bir dergidir. Elif Kutlu'nun editörlügüünde hazırlanan dergi Kurumsal İletişim Müdürlüğü tarafından hazırlanmaktadır. Dergi e-posta ve intranette kurumun tüm çalışanlarıyla ve web sayfasında tüm paydaşlarıyla paylaşılmaktadır. 2020 yılında 22. sayı olarak toplam 72 sayfa çıkarılan derginin bölümleri; Genel Müdür yazısı, Güncel, Ana Haber, Haber, Okuma Köşesi, iştiraklerinden haberlerin yer aldığ1 Sinerji, Sosyal Etkinlik Kulubü'nün yer aldığı SEK, Tüpraş'tan son gelişmelerin aktarıldığı Dinamik Tüpraş, İnfokrafik, Seyahat, Spor, Sanat, Sağlıklı Yaşam ve Sosyal Sorumluluk sayfalarından oluşmaktadır.

Opet' in 2012 yılında çıkarmaya başladığ 1 Kilometre dergisi üç ayda bir yayımlanmakta olup çalışmada Aralık 2020 sayısı incelemeye dahil edilmiştir. 2020 yılının 5. sayısı olarak çıkarılan, editörlügünü Pelin Çolak'ın yaptığı ve toplam 62 sayfa olan bu sayıda; OPET Yönetim Kurulu Başkanı ve Genel Müdür yazıları, Opet'ten haberler sayfası altında; seyahat, kurumun aldığı ödüller, Cem Yılmaz ile röportaj, Opet istasyonlarının tanıtımı, kurum reklamları, Yönetim Kurulu Üyesinin makalesi, Covid-19 için alınan iş güvenliği önlemleri, sosyal sorumluluk projeleri, çalışanlardan haberler, müşterilerden haberler, hizmet tanitımları, tarih, toplumsal sorunlar, spor, bayilerden haberler, uzmanların makaleleri, sağlık ve beslenme hakkında yazılar bulunmaktadir.

\section{Araştırmanın Amacı ve Önemi}

$\mathrm{Bu}$ çalışma ile kurumsal iletişimde kurumsal dergilerin ne kadar etkili kullanıldığını ortaya koymak amaçlanmaktadır. Literatürde kurumsal iletişim veya kurumsal dergiler hakkında yayınlar bulunmaktayken; kurumsal iletişim aracı olarak kurumsal dergileri konu alan çok fazla 
çalışmaya rastlanmamıştır. Bu çalışma kurumsal iletişimde kurumsal dergilerin rolünü ortaya koyması bakımından özgün bir çalışmadır.

\section{Araştırmanın Örneklemi}

Araştırmanın evreni Capital tarafından yapılan ve en büyük 500 özel şirketin yer aldığı “Capital 500" 2020 araştırma sonuçlarında (www.capital.com.tr) ilk 10 da yer alan firmaların elektronik ortamda yayınladığı kurumsal dergilerdir. Araştırmanın örneklemini enerji ve petrol alanında faaliyet gösteren ilk sıradaki Tüpraş "Rafine" ve dördüncü sıradaki Opet Petrolcülük tarafından çıkarılan "Kilometre" adında elektronik ortamda yayınlanan kurumsal dergiler oluşturmaktadır. Rafine Dergisinin 22. sayısı ve Kilometre Dergisinin 2020 yılında çıkarılmış olan 5. sayısı incelemeye alınmıştır

\section{Araştırmanın Yöntemi}

Araştırmada online olarak çıkarılan dergiler içerik analizi yöntemiyle incelenmiştir. Cornelissen ve arkadaşlarının (2006), Van Riel ve Fombrun (2007), Goodman (2004) ve Christensen ve arkadaşlarının (2009) çalışmalarından yola çıkılarak kurumsal iletişimin temel boyutları olarak; kurumsal kimlik, kurumsal davranış, kurumsal imaj, kurumsal vatandaşlık, kurumsal itibar ve kurum kültürü unsurları belirlenmiştir. Çalışmada; Koçer (2017)'in makalesinde yer alan kurumsal iletişim araçları, kurum kimliği, kurum kültürü ve kurumsal davranış ölçekleri kullanılmıştır. Kurumsal imajın ölçümünde Uluçay (2018)'in makalesinde yer alan unsurlardan yararlanılmıştır. Kurumsal vatandaşlık ölçeği; Marsden (2000) ve Lindgreen ve Swaen (2005)'ın çalışmalarından yola çıkılarak yazarlar tarafından oluşturulmuştur. İncelenen kurumsal dergilerin web siteleri, kurumsal iletişim uygulamalarında yer alan tablolardaki unsurlar açısından yazınsal bölüm, resim ve video içeriklerinde taranmıştır. Bu unsurları destekleyecek görüntü, kelime, uygulama ya da ifadeler esas alınmıştır. 


\section{Araştırmanın Bulguları}

Tablo 1'de incelenen kurumsal dergilerin web sitelerinin linkleri yer almaktadır.

Tablo 1. Incelenen Kurumlar ve Kurumsal Dergiler

\begin{tabular}{lll}
\hline Sıra & Dergi Adı & Web Sitesi Adresi \\
\hline 1 & Rafine Dergisi & https://www.tupras.com.tr/uploads/dergi-rafineri- \\
& (Tüpraş) & html/Rafine22/index.html \\
2 & $\begin{array}{l}\text { Kilometre Dergisi } \\
\text { (Opet) }\end{array}$ & https://kilometre.opet.com.tr/p/pdf.html \\
& & \\
\hline
\end{tabular}

Kurumsal Dergilerde Yer Alan Kurumsal İletişim Faaliyetleri: Tablo 2'de kurumsal dergilerde yer alan kurumsal iletişim tarafları ele alınmıştır. Kurumsal dergilerin kurumsal iletişim tarafları 9 maddede incelenmiştir.

Tablo 2. Kurumsal Iletişimin Tarafları

\begin{tabular}{lll}
\hline Dergi Adı & Rafine Dergisi & Kilometre Dergisi \\
\hline Çalışanlar & $\checkmark$ & $\checkmark$ \\
Tedarikçiler & $\checkmark$ & \\
Bayiler & & $\checkmark$ \\
Devlet & $\checkmark$ & $\checkmark$ \\
Medya ile İlişkiler & $\checkmark$ & $\checkmark$ \\
Yatırımcılar & $\checkmark$ & $\checkmark$ \\
Müşteriler & $\checkmark$ & $\checkmark$ \\
STK & $\checkmark$ & $\checkmark$ \\
Siyasi Gruplar & & \\
Toplam & 7 & 7 \\
\hline
\end{tabular}

Rafine dergisi kurumsal iletişim tarafları açısından çalışanlar, tedarikçiler, devlet, medya ile ilişkiler, yatırımcılar, müşteriler, sivil toplum kuruluşlarına yer verirken; Kilometre dergisi çalışanlar, bayiler, devlet, medya ile ilişkiler, yatırımcılar, müşteriler ve sivil toplum kuruluşlarına yer vermiştir. Kilometre dergisinde Opet Etnoköy projesini pandemi nedeniyle online basın toplantısı ile kamuoyuna duyurmuştur. Tüpraş ise Rafineri Dergisinde video paylaşımı olarak yayımladı̆̆ 2019 sürdürülebilirlik raporu ile kurumsal yapı ve faaliyetler hakkında paydaşlarına detaylı bilgiler sunmaktadır. 
Tablo 3'de kurumsal dergilerde yer alan kurumsal iletişim araçları 8 maddede incelenmiştir.

Tablo 3. Kurumsal Iletişim Araçları

\begin{tabular}{lll}
\hline Dergi Adı & Rafine Dergisi & Kilometre Dergisi \\
\hline Adres ve internet adresi & $\checkmark$ & $\checkmark$ \\
Tel no & $\checkmark$ & $\checkmark$ \\
Faks no & & $\checkmark$ \\
e-posta & & \\
Sosyal Medya & $\checkmark$ & \\
Harita & & \\
Yönetici Açı. & $\checkmark$ & $\checkmark$ \\
Medya Arşivi & $\checkmark$ & $\checkmark$ \\
Toplam & 5 & 5 \\
\hline
\end{tabular}

Kurumsal iletişim aracı olarak Rafine Dergisi; adres, telefon, sosyal medya, yönetici açıklamaları ve farklı konularda videoların yer aldığı medya arşivine yer vermektedir. Kilometre Dergisi ise; ise adres, telefon, faks numarası, yönetici açılamaları ve videoların yer aldığı bir içerik oluşturmuştur. Tüpraş, rafineri çalışanlarının inovasyon, teknoloji vb. konularda paylaşım yapabileceği Inowhatif Talks etkinlikleri ile ilgili bir e-posta adresi ve sürdürülebilirlik raporunun yer aldığı paylaşımında kurumsal iletişime ait bir e postaya yer vermiştir. Opet de benzer bir şekilde sadece kadıngücü projesine yönelik bir e-posta adresi paylaşmıştır.

Rafineri dergisinde facebook, twitter, Instagram ve linkedin hesapları yer alırken, Kilometre dergisinde herhangi bir sosyal medya adresi yer almamaktadır. Harita ve basın bülteni iki dergi açısından da kullanılmamıştır

Tüpraş Rafineri dergisi; imaj filmi, topluma katkı sağlayan proje videoları, Tüpraş ve Mili Eğitim Bakanlığı işbirliği ile açlan pandemi sürecine destek olmak amaciyla siperlikli maske üretimini hedefleyen kodlama sınıflarında görev alan öğretmenlerin mesajları, istihdamda kadın erkek eşitliğini vurgulayan mesajlar, çalışanların evlerinde çekerek biraraya getirdikleri milli bayram mesajları, çalışanların çocuklarının 23 Nisan mesajları, sporcuların 19 Mayıs Gençlik ve Spor bayramı mesajları ve çalışanların enerji verimliliği ile görüşlerinin yer aldığı videolara dergi içeriğinde yer vermektedir. 
Opet Kilometre dergisinde ise; reklam filmleri, karantina döneminde kuryelere teşekkür amacıyla hazırladığı ödüllü film, ödül törenleri ve pandemi nedeniyle online ortamda yayınlanan teşekkür mesajları, yöneticilerin katıldığ 1 online sohbetler video sayfa içeriğinde yer almaktadır. Sosyal sorumluluk kampanyalarının tanıtıldığı videolarda Opet'in ortağı olan Koç grubunun projenin en büyük destekçisi olduğu belirtilmektedir.

İki dergide de bu unsurların varlığı dijital ortamın sağladığı olanaklarla dergi sayfa sayısını arttırmadan dergi içeriğini zenginleştirmeye katkı sağlamaktadır.

Kurumsal Dergilerin Kurumsal İletişim Uygulaması Olarak Kurumsal Kimlik Unsurlarn: Tablo 4'de kurumsal kimlik unsurlar1 10 kriterde incelenmiştir.

\section{Tablo 4. Kurumsal Kimlik Unsurları}

\begin{tabular}{lll}
\hline Dergi Ad1 & Rafine Dergisi & Kilometre Dergisi \\
\hline İsim & $\checkmark$ & $\checkmark$ \\
Amblem & $\checkmark$ & $\checkmark$ \\
Slogan & $\checkmark$ & $\checkmark$ \\
Renk & $\checkmark$ & $\checkmark$ \\
Yazı Stili & $\checkmark$ & $\checkmark$ \\
Dil Seçenek & & \\
Gönder Bayrağ1 & $\checkmark$ & $\checkmark$ \\
Araç Giydirme & & $\checkmark$ \\
İç Görüntü & $\checkmark$ & $\checkmark$ \\
Diş Görüntü & $\checkmark$ & $\checkmark$ \\
Toplam & 8 & 9 \\
\hline
\end{tabular}

Her iki dergi de benzer şekilde isim, amblem, slogan, renk, yazı stili, gönder bayrağı, iç ve dış görüntü unsurlarına yer vermiştir. Kilometre dergisinde Opet'e ait bir araç giydirme görseli kullanılmıştır.

Tüpraş, çalışanların, pandemi sürecinde üretimin sürekliliğini sağlamak amacıyla yaptıkları çalışmaları anlatan imaj filmi "Lüksümüz Yok" sloganıla video olarak dergide yer almaktadır.

Opet ise Temiz Tuvalet kampanyası ve kadınlara çalışma hayatında fırsat eşitliğini savunan Kadın Gücü projesi gibi kurumu güçlü ve farklı olarak vurgulamayı hedefleyen çalışmalara destek olarak “Opet'se Fark 
Eder" sloganını kullanmaktadır. Reklam filmi de aynı sayfada video olarak yer almaktadır.

Tablo 5'de yer alan kurumsal davranış unsurları açısından iki dergide yapılan değerlendirmede belirlenen kriterler açından Tüpraş'ın 14, Opet'in ise 13 kriteri dergiye taşıdığı görülmektedir.

Tablo 5. Kurumsal Davranış Unsurları

\begin{tabular}{|c|c|c|c|}
\hline & & $\begin{array}{l}\text { Rafine } \\
\text { Dergisi }\end{array}$ & $\begin{array}{l}\text { Kilometre } \\
\text { Dergisi }\end{array}$ \\
\hline \multirow[t]{3}{*}{ Ekonomik davranış } & Sanayi kuruluşları ile ilişkiler & $\checkmark$ & \\
\hline & $\begin{array}{l}\text { STK ve meslek kuruluşları ile } \\
\text { ilişkiler }\end{array}$ & $\checkmark$ & $\checkmark$ \\
\hline & $\begin{array}{l}\text { Yurtdışındaki kurum ve } \\
\text { işletmelerle ilişkiler }\end{array}$ & $\checkmark$ & $\checkmark$ \\
\hline \multirow[t]{3}{*}{ Toplumsal davranış } & Toplumsal bilgilendirme & $\checkmark$ & $\checkmark$ \\
\hline & Sosyal sorumluluk kampanyaları & $\checkmark$ & $\checkmark$ \\
\hline & Etik Kurallar & $\checkmark$ & $\checkmark$ \\
\hline \multirow[t]{3}{*}{ Siyasi davranış } & $\begin{array}{l}\text { Toplumsal olaylar karşısında } \\
\text { yayımlanan mesajlar }\end{array}$ & $\checkmark$ & $\checkmark$ \\
\hline & Merkezi yönetimlerle ilişkiler & $\checkmark$ & $\checkmark$ \\
\hline & Yerel yönetimlerle ilişkiler & $\checkmark$ & $\checkmark$ \\
\hline \multirow[t]{3}{*}{ Kalite davranışı } & Kalite alanında bilgilendirme & $\checkmark$ & $\checkmark$ \\
\hline & Kurum Ödülleri & $\checkmark$ & $\checkmark$ \\
\hline & Bireysel Ödüller & $\checkmark$ & $\checkmark$ \\
\hline \multirow{3}{*}{$\begin{array}{l}\text { Çalışan/Yönetici } \\
\text { davranışı } \\
\text { Toplam }\end{array}$} & Törenlerde yer alma & $\checkmark$ & $\checkmark$ \\
\hline & Genel protokol & $\checkmark$ & $\checkmark$ \\
\hline & & 14 & 13 \\
\hline
\end{tabular}

Tüpraş tarafından çıkarılan Rafine dergisinde Tüpraş Genel Müdürü İbrahim Yelmenoğlu'nun Covid-19 salgınına ilişkin açıklaması yer almaktadır. "Üretimimizin kesintisiz sürmesini sağlayacak senaryoları gözden geçirerek olası gelişmelere göre aksiyon planlarımızı hazırladık", "İş süreçlerimizi güncel gelişmelere göre yeniden tasarladık", "Başta sahadaki çalışma arkadaşlarımız olmak üzere hepiniz bu anlayışla pandemi sürecinde işlerinizin başında oldunuz, ülkemizin enerji ihtiyacının karşılanmasında stratejik bir önem taşıdığımız için üretimimizin sürekliliğini ulusal bir sorumluluk olarak görüyoruz" şekinde açıklamaları ile toplumsal olaylar karşısındaki kurumsal davranışı, çalışanların işe yaklaşımını, kurumun yenilikler karşısındaki tavrını ve sürekliliğe verdikleri önemi vurgulamaktadırlar. 
Tüpraş, Milli Eğitim Bakanlığı ile birlikte yürüttüğü “Enerjimiz Geleceğe; Kodluyorum, Modelliyorum, Üretiyorum" projesi ile Koç Topluluğu içinde Ülkem İçin 2019 ödülünü kazanmıştır. Bunun yanısıra Tüpraş kurumsal bazda Enerji Verimliliği ödülü, Yükselen Yıldız Ödülü, İhracatın Yıldızları Sektör Ödülü ve Ege Bölgesi Sanayi Odası'ndan da iki ödül almaya hak kazanmıştır.

Opet Genel Müdürü Cüneyt Ağca "Yılın son günlerinde sağduyu ve dikkatle tedbiri elden bırakmamız gerektiğini birkez daha hatırlatmak isterim" ifadesi ile pandemiye dikkati çekmektedir. Kurumsal olarak alınan önlemler ve titizlikle uygulanan tedbirler sonucu TSE Covid 19 güvenli hizmet ve güvenli üretim belgesinin alınması da kurumun toplumsal bir olay karşısındaki tavrını yansıtmaktadır.

Kilometre dergisi 2020 Aralık sayısında Opet'in aldığı ödüllere yer verilmektedir. Opet, Yıldız Teknik Üniversitesi istatistik bölümünün katkılarıyla Türkiye İtibar Akademisi tarafından gerçekleştirilen Türkiye İtibar Endeksi 20020' de dokuzuncu kez “Akaryakıt Sektörünün En İtibarlı Markası" seçilmiştir. Aynı zamanda Stevie Awards for Great Employers'ta üç kategoride birincilik alırken "Çalışan İlişkilerinde Başarı" kategorisinde ödüle layık görülen tek şirket olmuştur. "İnsan Kaynakları Yönetiminde Başarı" kategorisinde gümüş, "Team of the Year" kategorisinde de bronz ödüle hak kazanmıştır. Bu ödüller kurumun çalışan memnuniyetine verdiği önemi göstermektedir. "Yeni Nesil İstasyon" reklam filmi serisiyle Effie Türkiye Reklam Etkinliği Ödüllerinde Gümüş Effie, karantina döneminde çalışan kuryelere teşekkür ettiği filmiyle de Felis Ödüllerinde "PR, Konu, Gündem ve Kriz Yönetimi" kategorisinde büyük ödülün sahibi olmuştur.

Opet'in Arkeo köy ve etno köy projeleri, Çıplak Köy Halk Eğitim Merkezi ile gerçekleştirdikleri kişisel gelişim, yöresel gıda ürünleri yapımı, diksiyon, iş güvenliği, iletişim vb. pek çok konuda verilen eğitimler, Kadın Gücü Projesi, Temiz Tuvalet Kampanyası gibi sosyal sorumluluk çalışmaları yaparken Tüpraş da siperli maske üretimi, sokak hayvanlarının beslenmesi, sağlık malzemeleri desteği vb. faaliyetleri sürdürmektedir. İki kurum da pandemi sürecine ilişkin çalışan ve toplumu bilgilendirme çalışmaları yapmıştır. 
Kurumsal Dergilerin Kurumsal İletişim Uygulaması Olarak Kurumsal Imaj: Tablo 6'da kurumsal imaj unsurları yer almaktadır. Kurumsal imajın ölçümünde çalışanların imaj unsurları, yönetimin imaj unsurları ve sosyal sorumluluk boyutlarında toplam 23 alt boyutta dergiler taranmıştır.

Tablo 6. Kurumsal İmaj Unsurları

\begin{tabular}{|c|c|c|c|}
\hline & & $\begin{array}{l}\text { Rafine } \\
\text { Dergisi }\end{array}$ & $\begin{array}{l}\text { Kilometre } \\
\text { Dergisi }\end{array}$ \\
\hline Çalışanların İmaj & Üretkendir & $\checkmark$ & $\checkmark$ \\
\hline \multirow[t]{11}{*}{ Unsurları } & Çalışanlar iş ahlakına sahiptir. & $\checkmark$ & $\checkmark$ \\
\hline & Çalışanlar niteliklidir. & $\checkmark$ & $\checkmark$ \\
\hline & Çalışanlar işlerini istekli yapar. & $\checkmark$ & $\checkmark$ \\
\hline & Çalışanlar ilgili ve yardımseverdir. & $\checkmark$ & \\
\hline & Sunduğu hizmetler güvenilirdir. & $\checkmark$ & $\checkmark$ \\
\hline & Yeniliklere açıktır. & $\checkmark$ & $\checkmark$ \\
\hline & İşyeri ve olanakları moderndir & $\checkmark$ & $\checkmark$ \\
\hline & $\begin{array}{l}\text { Sosyal tesisleri (yeme-içme alanları, spor salonu, } \\
\text { barınma vb.) yeterlidir }\end{array}$ & & \\
\hline & $\begin{array}{l}\text { Çalışma alanları (ofisler, atölyeler,vb.) fiziksel } \\
\text { olarak sağlıklı bir yapıdadır (havalandırma, } \\
\text { ışıklandırma vb.) }\end{array}$ & $\checkmark$ & $\checkmark$ \\
\hline & Huzurlu bir çalışma ortamı vardır & $\checkmark$ & $\checkmark$ \\
\hline & $\begin{array}{l}\text { Çalışan işyerinde kendisine değer verildiğini } \\
\text { hisseder. }\end{array}$ & $\checkmark$ & $\checkmark$ \\
\hline \multirow[t]{6}{*}{$\begin{array}{l}\text { Yönetimin İmaj } \\
\text { Unsurları }\end{array}$} & $\begin{array}{l}\text { Görüşlerini açık ve dürüst bir biçimde } \\
\text { aktarır. }\end{array}$ & $\checkmark$ & $\checkmark$ \\
\hline & Yöneticiler yönetmeliğe uygun ve etik davranır. & $\checkmark$ & $\checkmark$ \\
\hline & Yönetim şikâyetleri dikkate alır & $\checkmark$ & \\
\hline & $\begin{array}{l}\text { Çalışanların yönetimde temsil ve katılım gücü } \\
\text { vardır. }\end{array}$ & $\checkmark$ & \\
\hline & Yöneticiler başarılı ve yetkin kişilerdir & $\checkmark$ & $\checkmark$ \\
\hline & $\begin{array}{l}\text { İşbirliği içinde olduğu pek çok kurum ve kuruluş } \\
\text { vardır. }\end{array}$ & $\checkmark$ & $\checkmark$ \\
\hline Sosyal & Topluma hizmet eden sosyal projeleri destekler. & $\checkmark$ & $\checkmark$ \\
\hline \multirow[t]{4}{*}{ Sorumluluk } & Bilimsel, sanatsal ve kültürel etkinlikler düzenler & $\checkmark$ & $\checkmark$ \\
\hline & $\begin{array}{l}\text { Çeşitli toplumsal sorunları çözmeye katkı } \\
\text { sağlayacak projeler geliştirir. }\end{array}$ & $\checkmark$ & $\checkmark$ \\
\hline & $\begin{array}{l}\text { Sosyal, kültürel ve sanatsal faaliyetleri yerel ve } \\
\text { ulusal medyada sık sık yer alır. }\end{array}$ & & $\checkmark$ \\
\hline & Çevre sorunlarına karşı duyarlıdır. & $\checkmark$ & $\checkmark$ \\
\hline Toplam & & 21 & 19 \\
\hline
\end{tabular}

Tablo 6'ya göre kurumsal imaja yönelik unsurlardan Tüpraş 21, Opet ise 19 kriteri kurumsal dergilerine yansıtmıştır.

Tüpraş'ta topluma hizmet eden projelere örnek olarak “Enerjimiz Geleceğe; Kodluyorum, Modelliyorum, Üretiyorum" projesi ile Milli 
Eğitim Bakanlığı ile işbirliği içinde dört ilde 30 ortaöğretim okulunda Robotik Kodlama, Üç Boyutlu Modelleme ve Üretim Beceri Sınıfları kurulmuştur.

Pandemi süresince yapılan özverili çalışmalar için Yelmenoğlu'nun "Koronovirüs salgınının başından itibaren uzun saatler boyunca yılmadan vardiyeli çalışan arkadaşlarımıza ise özel olarak teşekkür etmek istiyorum" şeklindeki açıklaması çalışanların işyerinde kendisine değer verildiğini gösteren bir ifade olarak dikkati çekmektedir. İzmit, İzmir, Kırıkkale ve Batman tesislerinde görev alan işyeri hekimi ve sağlık çalışanlarına yönelik "Tüpraşlıların sağlığını korumak gibi büyük bir sorumluluğu üstlenen hekimlere minnetimizi ifade etmek için onları sayfalarımıza taşıdık" ifadesi de benzer bir yaklaşımı göstermektedir. Yelmenoğlu ayrıca "Tüpraşın her dönem en değerli sermeyesi olarak gördüğ̈u çalışanlarına sunduğu emniyetli çalışma ortamını geliştirmeye ve geleceğin nitelikli işgücünü yetiştirmeye hiç ara vermeden devam ediyoruz" ifadesi ile de çalışanlara verilen değer yanında çalışma ortamının iyileştirilmesi ve çalışan niteliklerine verilen önemi göstermektedir. Bununla birlikte çalışan ve yöneticilerin biraraya gelerek çeşitli konulardaki fikirlerini paylaştıkları "Kahve Molası" etkinlikleri de çalışan yönetici iletişimini arttırmaktadır. Ayrıca "Sahne Bizim" isimli etkinlikle çalışanların proje sunumları yapılmakta ve takımlararası işbirliği geliştirilmektedir. Opet ise "Müşteri memnuniyetine olduğu kadar çalışan mutluluğuna da büyük önem veriyoruz" “...güçlü iletişim ve mutlu çalışan deneyimi yaratmayı hedefliyoruz" yaklaşımıyla çalışanlara olan bakış açısını yansıtmaktadır.

Rafineri dergisinde özellikle pandemi döneminde iş ortamının (servis, çalışma alanı, ortak giyinme ve mola alanları, yemekhane) sağlıklı olmasını sağlamak amacıyla videolarla desteklenmiş bir anlatım görülmektedir. Ayrıca pandemi sürecinin etkisiyle ultraviyole ve dezenfeksiyon cihazının temin edilmesi işyeri olanaklarının değişen koşullara uyum gösterecek şekilde düzenlediğini de göstermektedir. 2020 yılı mart ayına kadar çalışanların birlikteliğini sağlamak amacıyla gezi, müzik, doğa, yelken, satranç vb. fiziksel faaliyetler düzenlenirken, pandemi sürecinde online tiyatro söyleşisi, sergi, atölye ve seminer gibi dijital ortamda yer alan etkinlikler ön plana çıkmaktadır. Tüpraş İzmit 
Rafinerisi "Sıfır Atık Belgesi" ni almaya hak kazanarak çevre sorunlarına karşı duyarlılığını göstermektedir.

Opet, pandemi ile de artan bir şekilde hem toplum hem de çalışan sağlı̆̆ını önceleyen çalışmalara yer vermekte ve topluma yönelik bilgilendirmeler yapmaktadır. Bu amaçla TSE Covid 19 Güvenli Hizmet ve Güvenli Üretim belgesi almıştır. Güçlü iletişim ve mutlu çalışan deneyimi yaratma hedefi dikkat çekerken, çalışan bağl1lığ ilişkilerinde başarı ödülleri uyumlu bir çalışma ortamının varlığına işaret etmektedir. Türkiye Odalar ve Borsalar Birliği Kadın Girişimciler Kurulu Başkanlığına seçilen Opet Yönetim Kurulu Üyesi Nurten Öztürk; Opet'in Temiz Tuvalet Kampanyası, Yeşil Yol, Örnek Köy, Tarihe Sayg1 ve Trafik Dedektifleri Projelerinin fikir lideri ve yöneticisi olarak amaçlarının doğaya, vatana ve yaşama saygılı projeler üretmek olduğunu belirtmektedir.

\section{Kurumsal Dergilerin Kurumsal İletişim Uygulaması Olarak Kurumsal} Vatandaşlık: Tablo 7'da kurumsal dergilerde yer alan vatandaşlık unsurları yer almaktadır. Kurumsal vatandaşlık 18 alt boyutta ele alınmıştır.

Kurumsal vatandaşlı̆̆a yönelik unsurlardan Tüpraş 18, Opet ise 17 kriteri kurumsal dergilerine yansıtmıştır.

Yelmenoğlu'nun pandemi sürecine yönelik açılamasında; Milli Dayanışma Kampanyasına yapılan nakdi yardım yanında Kocaeli Sağlık Müdürlügüne yapılan PCR test cihazı bağışı, belediye ve hastanelere maske, tulum ve kolonya yardımı, koruyucu siperlik üretimi için Milli Eğitim Bakanlığ1 Temel Eğitim Genel Müdürlüğü ile işbirliği içinde yapılan çalışmalar ve hayvanlara yönelik Körfez ve Aliağa belediyeleri ile işbirliği yaparak beslenme ve barınma destekleri de yer almaktadır. Sosyal sorunlar ve hayvanlara yönelik projeler, devletle projelerde işbirliği, gönüllü hayırseverlik gibi kurumsal vatandaşlık kriterleri ön plana çıkmaktadır.

8 Mart Dünya kadınlar günü vesilesiyle yapılan etkinliklerde "Tüpraş'ta kadın erkek omuz omuza çalışıyoruz", "Gücümüzü eşitlikten alıyoruz" ifadeleri ile çalışanlar arasındaki işbirliği ve uyuma dikkat çekilmektedir, Ayrıca eşitlik ve kapsayıcılık prensibiyle kadınların güçlenmesi için toplumsal farkındalık yaratmak adına Fenerbehçe Spor 
Kulubü ve Birleşmiş Milletler Kadın Biriminin yürüttüğü HeForShe hareketine de katılım sağlanmıştır.

Tablo 7. Kurumsal vatandaşlık unsurları

\begin{tabular}{lll}
\hline Uygulamalar & Rafine & Kilometre \\
& Dergisi & Dergisi \\
\hline Toplum değerlerine uyma & $\checkmark$ & $\checkmark$ \\
Etik kurallara uyma & $\checkmark$ & $\checkmark$ \\
Çevresel sorunlara yönelik projeler yapma & $\checkmark$ & $\checkmark$ \\
Sosyal sorunlara yönelik projeler yapma & $\checkmark$ & $\checkmark$ \\
Eğitime yönelik projeler yapma & $\checkmark$ & $\checkmark$ \\
Hayvanlara yönelik projeler yapma & $\checkmark$ & \\
Çeşitli topluluklara destek & $\checkmark$ & $\checkmark$ \\
İnsancıl örgüt kültürü & $\checkmark$ & $\checkmark$ \\
Çalışanlar arasında işbirliği ve uyum & $\checkmark$ & $\checkmark$ \\
Yasalara uygun faaliyetler yapma & $\checkmark$ & $\checkmark$ \\
Kalite belgelerinin olması (ISO14001, SA8000 gibi) & $\checkmark$ & $\checkmark$ \\
Politika beyanatının olması & $\checkmark$ & $\checkmark$ \\
Sürdürülebilirlikle ilgili çalışmaların olması & $\checkmark$ & $\checkmark$ \\
Aktif sürdürülebilir liderlik & $\checkmark$ & $\checkmark$ \\
Gönüllü hayırseverlik & $\checkmark$ & $\checkmark$ \\
Doğal afetlerde resmi makamlara destek & $\checkmark$ & $\checkmark$ \\
Sivil Toplum Kuruluşlarılyla işbirliği & $\checkmark$ & $\checkmark$ \\
Devletle çeşitli projelerde işbirliği & $\checkmark$ & 17 \\
Toplam & $\checkmark$ & $\checkmark$ \\
\hline
\end{tabular}

Opet halk eğitim merkezi ortaklığı ile 2020 yılında çok farklı alanlarda verilen 1320 saatlik eğitimler, Etno köy ve kadın istihdamı arttırmaya yönelik Kadın Gücü projeleri ile toplumsal yaşama katkı sağlamaktadır. Pandemi sürecinde Çanakkale Halk Eğitim Merkezindeki maske ve siperlik üretimi ve üretilen materyellerin kamu kurum ve kuruluşlarına ulaşımına destek olunmuştur. Çalışan mutluluğu ve iletişimine yönelik alınan ödüller dikkati çekmekte ve kurumsal sürdürülebilirlik için verilen Bravo ödülü alan bayi görüşleri dergide yer almaktadır.

Kurumsal Dergilerde Yer Alan Kurumsal İletişim Uygulaması Olarak Kurumsal İtibar: Tablo 8'de kurumsal dergilerde kurumsal itibarm alt boyutları yer almaktadir.

Rafine dergisinde kurumsal itibar unsurları ürün ve hizmetler, çalışma ortamı, sosyal sorumluluk, kalite politikası, vizyon, sürdürülebilirlik, liderler ve finansal raporlar olmak üzere 8 , Kilometre Dergisinde ürün ve hizmetler, çalışma ortamı, sosyal sorumluluk, kalite politikası, 
sürdürülebilirlik, kurumsal vizyon ve liderler olmak üzere 7 kriter yer almıştır.

Tablo 8. Kurumsal itibar unsurlar

\begin{tabular}{lll}
\hline Kurumsal İtibar Boyutları & Rafine Dergisi & Kilometre Dergisi \\
\hline Ürün ve Hizmetler & $\checkmark$ & $\checkmark$ \\
Çalışma Ortamı & $\checkmark$ & $\checkmark$ \\
Sosyal Sorumluluk & $\checkmark$ & $\checkmark$ \\
Kalite Politikası & $\checkmark$ & $\checkmark$ \\
Kurumsal Vizyon & $\checkmark$ & $\checkmark$ \\
Sürdürülebilirlik & $\checkmark$ & $\checkmark$ \\
Liderler & $\checkmark$ & $\checkmark$ \\
Finansal raporlar & $\checkmark$ & \\
Toplam & 8 & 7 \\
\hline
\end{tabular}

Kuruluşun performansının gelişimini sağlayan EFOM modeli ile Tüpraş, kurumsal mükemmellik yolculuğunda mükemmellik yetkinlik seviyesine ulaşmıştır. Tedarik zincirinden satış sonrası operasyonlara kadar sürdürülebilirliğin entegre edildiği Tüpraş Rafineri dergisinde 2019 sürdürülebilirlik raporunu yayımlamıştır.

Opet günümüz koşulları ile örtüşen temizlik ve hijyen unsurlarının ön plana alındığı 20 yıl önce başlayan Temiz Tuvalet Projesi ve Sürdürülebilirlik Akademisinin düzenlediği Sürdürülebilirlik İş Ödüllerine layık görülen Arkeo-Köy Tevfikiye ve Kadın Gücü Projesi ile sürdürülebilirlik anlayışını yansıtmaktadır. Bununla birlikte akaryakıt istasyon ve personelinin performasının değerlendirildiği Bravo sistemi ile kurumsal standardın sürdürülebilirliği hedeflenmektedir.

\section{Kurumsal Dergilerde Yer Alan Kurumsal İletişim Uygulaması Olarak} Kurum Kültürü Unsurları: Tablo 9'da kurumların kurum kültürü incelenmiştir.

Kurum kültürü unsurları açısından Tüpraş ve Opet 10 kriteri dergilerine yansıtmıştır. Farklı olarak Tüpraş sürdürülebilirlik raporunda kurumsal bilgilere yer verirken, Opet videolarda tarihsel geçmişine yer vermiştir.

Tüpraş, ülkenin enerji ihtiyacının karşılanmasında stratejik bir öneme sahip olma bilinciyle üretimin sürekliliğini ulusal bir sorumluluk olarak görme, toplumun değişim ve dönüşümüne öncülük etme, sektörde 
eşitlikçi ve kapsayıcı iş ortamı oluşturma, kurumsal sponsorluklarıyla sanat ve kültüre sürdürülebilir bir alan oluşturma gibi temel değerleri benimsemiştir.

Tablo 9. Kurum Kültürü Unsurları

\begin{tabular}{lll}
\hline Kültür Unsurları & Rafine Dergisi & Kilometre Dergisi \\
\hline Kuruluş Hakkında Bilgi & $\checkmark$ & \\
Temel değerler & $\checkmark$ & $\checkmark$ \\
Vizyon & $\checkmark$ & $\checkmark$ \\
Misyon & $\checkmark$ & $\checkmark$ \\
Amaçlar & $\checkmark$ & $\checkmark$ \\
Politikalar & $\checkmark$ & $\checkmark$ \\
Etik ilkeler & $\checkmark$ & $\checkmark$ \\
Slogan & $\checkmark$ & $\checkmark$ \\
Yönetim Kurulu & $\checkmark$ & $\checkmark$ \\
Tarihçe & & $\checkmark$ \\
Törenler & $\checkmark$ & $\checkmark$ \\
Toplam & 10 & 10 \\
\hline
\end{tabular}

Opet koşullar ne olursa olsun çalışmaya, üretmeye ve hayatı sürdürmeye odaklı bir anlayışı benimsemektedir. Müşteri ve çalışan mutluluğu yanında sürekli öğrenme ilkesi önem taşımaktadır. Ayrıca Opet Genel Müdürü Cüneyt Ağca en önemli değerin kamuoyu güvenini kazanmak olduğunu ve müşteri memnuniyeti odaklı hizmet kalitesini benimsediklerini belirtmektedir.

Rafineri dergisinde kurumsal ödüller, pandemi sürecine ilişkin bilgilendirmeler, çalışanların içinde yer aldığ 1 faaliyetler, sanata kültür ve spora katkı, kitap tanıtımı, Batman ili tanıtımı, yönetici açıklamaları gibi konular ele alınmıştır. Özellikle dergide video olarak yer alan sürdürülebilirlik raporu kriterler açısından detaylı bilgi vermektedir.

Kilometre dergisi ise, kurucu ve yönetici açıklamaları, projeler hakkında bilgi, alınan ödüller, reklam filmleri, pandemiye yönelik önlem ve bilgilendirmeler, kurumsal lider ve paylaşımları, bayilerle ilişkiler, yenilikler, spor ve kültüre katkı, Z kuşağı, bağışıklık ve depresyon gibi toplumsal konular hakkında bilgiler içermektedir.

Tablo 10'da iki derginin kurumsal iletişim alanında aldığı toplam puanlar yer almaktadır. Dergiler toplam 101 puan üzerinden incelenmiştir. Rafine Dergisi toplamda 91 puan alırken, Kilometre dergisi 87 puan almıştır. Rafine dergisi kurumsal davranış, kurumsal imaj, 
kurumsal vatandaşlık ve kurumsal itibar konusunda dergi içeriğinde Kilometre Dergisine göre daha yüksek puanlar alırken, Kilometre dergisi de kurumsal kimlik unsurları açısından daha yüksek puan almıştır.

Tablo 10. Kurumsal iletişim uygulamaları toplamı

\begin{tabular}{lll}
\hline & Rafine Dergisi & Kilometre Dergisi \\
\hline Kurumsal İletişim Tarafları & 7 & 7 \\
Kurumsal İletişim Araçları & 5 & 5 \\
Kurumsal Kimlik Unsurları & 8 & 9 \\
Kurumsal Davranış Unsurları & 14 & 13 \\
Kurumsal İmaj Unsurları & 21 & 19 \\
Kurumsal Vatandaşlık Unsurları & 18 & 17 \\
Kurumsal İtibar Unsurları & 8 & 7 \\
Kurumsal Kültür Unsurları & 10 & 10 \\
Toplam & 91 & 87 \\
\hline
\end{tabular}

\section{Sonuç}

Kurumsal iletişim bir yönetim fonksiyonu olarak pek çok boyutta ve eşzamanlı yapılan karmaşık bir süreçtir. Kurumsal iletişim işletmenin çalışanları, yatırımcıları, tedarikçileri, dağıtımcıları, müşterileri ve içinde faaliyet gösterdiği toplumun devlet mekanizmaları ve toplumun diğer üyeleriyle olan iletişim süreçlerini kapsar. Kurumsal iletişim en üst düzey yöneticiden, en alt düzey çalışana kadar uzanan bir uygulayıcılar takımını gerektirmektedir.

Kurumsal iletişim sürecinde profeyonel uzman gruplar görevlendirilir. Kurum kimliği, kurumsal imaj, kurumsal vatandaşlık, kurumsal itibar, kurum kültürü, devletle resmi ilişkiler, topluluklarla ilişkiler, iç iletişim, kurumsal sosyal sorumluluk, kriz yönetimi, lobicilik, reklamlar ve halkla ilişkiler gibi uygulamalar aracılığıyla yürütülür.

Kurumsal iletişimde kurumsal web sayfaları, kurumların sosyal medya mecraları, reklam, basın toplantıları, basın bültenleri, yıllık faaliyet raporları, kurum içi iletişim ağı, telefon, faks, elektronik posta ve kurumsal dergiler gibi pek çok araç kullanılmaktadır. Kurumsal dergiler iletişim uzmanları tarafından periyodik olarak hazırlanır. Kurumsal dergilerde yönetici konuşmaları, kurumdan haberler, kurumun başarıları, çalışandan haberler, sektör gelişmeleri gibi sayfalar bulunmaktadır. Kurumsal iletişim dergileri kaliteli görselleri, geniş içerikleri, 
saklanabilmesi bakımından kurumlar tarafından kurumsal iletişimde tercih edilen araçlardır.

Son yıllarda kurumsal dergiler hızlı hazırlanabilmesi, kaliteli görsel ve video haber kullanımı ve daha çok sayfa bulundurma avantajları nedeniyle elektronik ortamda çıarılmaya başlanmıştır. Bu çalışmada da Tüpraş' in kurumsal online dergisi olan Rafine ve Opet'in kurumsal online dergisi olan Kilometre dergileri içerik analizi yöntemiyle incelenmiştir. Bu dergiler kurumsal iletişimin tarafları, iletişim ortamları, kurumsal iletişim uygulamaları alt boyutlarında incelenmiştir. Çalışmanın amacı kurumsal dergilerin kurumsal iletişimin uygulamalarına ne kadar yer verdikleri ve kurumsal iletişim aracı olarak ne kadar etkili olduklarını tespit etmektir.

Dergiler toplam 101 puan üzerinden değerlendirilmiştir. Rafine dergisi toplamda 91 puan alırken; Kilometre dergisi 87 puan almıştır. Rafine dergisi; kurumsal davranış ve kurumsal vatandaşlık ve kurumsal itibar boyutlarında tam puan alırken; Kilometre dergisi kurum kimliği unsurlarına yer vermede daha yüksek puan almıştır. Kurumsal iletişim tarafları, kurumsal iletişim araçları ve kurumsal kültür unsurları açısından ise her iki dergi de eşit puan almıştır.

Her iki dergi de yönetici yazılarıyla başlamaktadır. Kurumsal iletişim tarafları açısından siyasi gruplar, kurumsal iletişim araçları açısından harita bilgileri, kurumsal kimlik unsurlarından dil seçeneği her iki dergide yer almamaktadır. Adres, internet adresi ve telefon bilgilerinin yer aldığı sayfada iki dergi de kuruma ait bir e-posta adresi vermemiştir. Rafine dergisi son sayfasinda sosyal medya hesaplarına yer verirken, Kilometre dergisinde bu yönde bir paylaşım görülmemektedir.

Kurumların aldığı ödüller dergilerde geniş yer bulmaktadır. Her iki dergi de çalışanlarına gerek yaptıkları etkinlikler gerekse aldıkları ödüller nedeniyle geniş yer vererek kurum içi iletişime dikkat çekmektedir. Her iki dergi de eğitim çevre ve korona nedeniyle yaşanan toplumsal sorunlarla ilgili yaptıkları sosyal sorumluluk faaliyetlerini dergi sayfalarına taşımıştır. Kilometre dergisi sürdürülebilirliğin önemini vurguladıkları, uzun yıllardır devam eden sosyal sorumluluk çalışmalarına video içerikleriyle ayrıntılı olarak değinmektedir. Rafine dergisi ise dergi içeriğinde yer alan sürdürülebilirlik raporunda finansal bilgilere yer vermektedir. Bu durum yatırımcı ilişkileri ve şeffaflık açısından büyük bir önem taşımaktadır. 
Online dergilerin önemli bir avantajı video haber bulundurma özelliğine sahip olmasıdır. Rafine dergisi diğer sayılarında olduğu gibi bu sayıda da video haber yapmıştır. Çalışanların farklı konulardaki mesajlarına yönelik video paylaşımlarına yer vermiştir. Kilometre Dergisinde de video haberler, yönetici konuşmaları ve reklam filmleri yer almaktadır.

Kurumsal dergiler incelenen kriterler açısından kurumsal iletişim uygulamalarına büyük ölçüde yer vermektedir. Kalıcı olması, herkesin erişimine açık olması, baskı maliyetinin olmaması, video haber ile içeriğin genişletilmesi ve kaliteli görselleri kullanması bakımından kurumsal online dergiler kurumsal iletişimin önemli araçlarıdır.

Sonuç olarak, kurumsal iletişim dergi içerik üreticilerinin; kurumsal iletişimin paydaşları olan müşteriler, tedarikçiler, yatırımcılar ve dağıtımcılara daha çok yer vermesi gerektiği söylenebilir. Bununla birlikte dergi içerik üretiminde çalışanların daha aktif olarak yer alması içeriğin zenginleştirilmesine katkı sağlayabilir. Çalışmada ele alınan kurumsal iletişim uygulamalarının kurumsal online dergilerin tek bir sayı üzerinden değerlendirilmesi sınırlılığına karşın diğer araştırmacıların daha çok dergi sayısı ile yapabileceği yeni çalışmalara temel teşkil edebileceği düşünülmektedir. 


\title{
EXTENDED ABSTRACT
}

\section{An Investigation on the Use of Corporate Journals in Corporate Communication}

\author{
Sevim Koçer - Neslihan Ölçer \\ Kocaeli University
}

This study examines Tüpraş's Rafine and Opet's Kilometre journals in terms of corporate communication. The study is original in terms of revealing the role of online corporate journals in the process of corporate communication. In the study, online journals were examined using the content analysis method. Corporate magazines were analyzed in terms of various elements such as the parties of corporate communication, corporate communication tools, corporate communication practices, corporate identity, corporate behavior, corporate image, corporate citizenship, corporate reputation, and corporate culture.

Rafine covers employees, suppliers, state, media relations, investors, clients, and non-governmental organizations as the parties of the corporate communication; while Kilometre gives space to employees, distributors, state, media relations, investors, clients, and nongovernmental organizations.

Rafine has a media archive containing addresses, phone numbers, social media posts, executive statements, and videos with similar other content. Meanwhile, Kilometre has content mainly containing address, phone number, fax number information, executive statements, and videos. Rafine provides links to Facebook, Twitter, Instagram, and LinkedIn accounts; while Kilometre doesn't publish any social media connection.

Rafine journal provides publicity for image movies, videos of projects contributing to the community, messages of teachers taking roles in coding classes that target face shield production to support the efforts against the pandemic, messages that emphasize gender equality in employment, joined videos of employees giving messages for national and religious days, and content that covers employees' opinions regarding energy efficiency. On the other hand, Opet's Kilometre mainly covers 
advertising films, an award-winning film prepared to say thanks to couriers for their endeavors during the pandemic, addressing videos that are published online for award ceremonies due to the pandemic, and videos of interviews made by executives of corporations.

Both journals include name, emblem, and slogan, color, writing style, union flag, internal and external visual elements as the elements of corporate identity. Tüpraş publishes the efforts made to ensure the continuity of the work during the pandemic with a video content built upon the motto of "Lüksümüz Yok" (We don't have the luxury). On the other hand, Opet uses the slogan "Opet'se Fark Eder" (Opet makes a difference), which strongly and uniquely highlights the company, using campaigns such as the "Kadın Gücü" (Women's Power) project, which advocates equality of opportunity for women in working life.

In Rafine, Tüpraş's General Manager's statements about the Covid-19 pandemic emphasize corporate behavior in the face of social events, the approach of employees to work, the attitude of the corporation in the face of innovations, and the importance they give to continuity. Opet's General Manager draws attention to the pandemic itself with his statements. The receipt of TSE Covid 19 Certificate of Safe service and Safe Production as a result of institutional measures and carefully implemented precautions also reflects the attitude of the institution towards the social events.

Opet's focus was on its archeo-village and ethno-village projects, personal development, local food production, diction, work safety, communication, and many other relevant training programs organized in cooperation with Çıplak Village Public Education Center, as well as social responsibility projects such as "Women's Power" and "Clean Toilets"; while Tüpraş continued its endeavors in the fields of face shield production, feeding street animals, providing medical aids, etc. Both institutions continued to inform their employees and the community about the developments regarding the pandemic.

Rafine shows that ultraviolet and disinfection devices are provided in order to ensure that the business environment is healthy during the pandemic, and workplace facilities are regulated in such a way as to adapt to changing conditions. Travel, music, excursion, sailing, chess tournaments, and similar other physical activities were held to ensure the unity of employees until March 2020, while digital activities such as online 
theater interviews, exhibitions, workshops, and seminars came to the fore during the pandemic. Tüprass's Izmit refinery is entitled to receive the "Zero Waste Certificate" showing its sensitivity to environmental problems.

Opet is increasingly involved in studies that prioritize community and employee health after the pandemic and provide information to the community. For this purpose, the company received the TSE Covid 19 Certificate of Safe Service and Safe Production. While the goal of creating strong communication and a happy employee experience stands out among others, employee loyalty and achievement rewards in employee relationships indicate the existence of a harmonious working environment.

Rafine also covers corporate reputation elements, products and services, working environment, social responsibility, quality policy, vision, sustainability, leaders, and financial reports. Kilometre covers products and services, working environment, social responsibility, quality policy, sustainability, corporate vision, and leaders.

Tüpraş has adopted core values such as regarding continuity of production as a national responsibility in meeting the country's energy needs, leading the community to change and transform, creating an equitable and inclusive work environment within the sector, and creating a sustainable space for art and culture through corporate sponsorships.

Opet adopts an understanding focused on working, producing, and sustaining life regardless of circumstances. Besides customer and employee happiness, the principle of continuous learning has a significant place. In addition, Opet executives state that the most important value of their journals is to gain public trust and to adopt customer satisfactionoriented service quality.

The journals were reviewed based on a total score of 101. Refine journal scored a total of 91, while Kilometre scored 87. Refined scored higher in corporate behavior, corporate image, corporate citizenship, and corporate reputation than Kilometre, which scored higher in terms of corporate identity elements. 


\section{Kaynakça / References}

Akım, F. (2015). Kurumsal itibarın yönetilmesinde halkla ilişkiler. S. Koçer (Ed). Halkla İlişkilerde Uzmanlaşma (içinde s.1-24). İstanbul: Derin.

Barutçugil, İ. (2013). Stratejik yönetim, İstanbul: Kariyer Yayınları.

Balmer, J. M.T. and Greyser, S. A. (2006). Corporate marketing: Integrating corporate identity, corporate branding, corporate communications, corporate image and corporate reputation. European Journal of Marketing, 40, 730-741.

Christensen, T. L., Firat, F. A. and Cornelissen, J. (2009). New tensions and challenges in integrated communications. Corporate Communications: An International Journal, 14(2), 207-219.

Cornelissen, J. (2004). Corporate communications theory and practice. London: Sage.

Cornelissen, J., Van Bekkum, T. and Van Ruler, B. (2006). Corporate communications: A practice-based theoretical conceptualization. Corporate Reputation Review, 9(2), 114-133.

Cornelissen, J. P., Haslam, S. A. and Balmer, J. M. T. (2007). Social identity, organizational identity and corporate identity: Towards an integrated understanding of processes, patternings and products. British Journal of Management, 18, 1-16.

Dinçer, Ö. (2013). Stratejik yönetim ve işletme politikası. 9. Baskı, İstanbul: Alfa Yayınları.

Flavian, C., Torres, E. and Guinalıu, M. (2004). Corporate image measurement a further problem for the tangibilization of internet banking services. The International Journal of Bank Marketing, 22(5), 366-384.

Fombrun, C. J. (1996). Reputation: Realizing value from the corporate image. Harvard Business School Press.

Gardberg, N. A._and Fombrun, C. J._(2006). Corporate citizenship: Creating intangible assets across institutional environments. Academy of Management Review, 31(2), 329-346.

Gemlik, N. ve Sığrı, Ü. (2007). Kurum imajı analizi ve bir belediye üzerindeki uygulamanın değerlendirilmesi. İstanbul Ticaret Üniversitesi Sosyal Bilimler Dergisi,11, 267-282.

Goodman, M. B. (2004). Today's corporate communication function. S. Oliver (Ed.). Handbook of Corporate Communication and Public Relations Pure and Applied (içinde s.200-227). London and New York: Routledge 
Gönenç, A. Y. (2006). Türkiye'de ve Fransa'da dergicilik ve kadın dergileri. İstanbul: İstanbul Ü. İletişim Fakültesi Yayınları.

Korkmaz, A. (2007). Yazılı basında kurum kimliğinin oluşturulması sürecinde kurum kimliği stratejisinin belirlenmesi. Selçuk Ü. Sosyal Bilimler Enstitüsü Dergisi, 7, 385-391.

Koçer S. (2017). Kurumsal web sitelerinin kurum kimliği açısından incelenmesi: En çok tercih edilen üniversiteler üzerine bir analiz. Uluslararası Sosyal Arastırmalar Dergisi, 10(53),756-772.

Lindgreen, A. and Swaen, V. (2005). Corporate citizenship: Let not relationship marketing escape the management toolbox. Corporate Reputation Review, 7(4), 346-363.

Marsden, C. (2000). The new corporate citizenship of big business: Part of the solution to sustainability? Business and Society Review, 105, 19-25.

Oliver, S. (2010). Public relations strategy. 3. Bask1, Londra: Kogan.

Schein, E. H. (1992). Organizational culture and leadership. San Francisco: JosseyBass Publishers.

Sinha, M. and Bhatia, P. (2016). Strategic corporate communication and impact in Indian service sector. Corporate Communications: An International Journal, 21(1), 120-140.

Toku, A. B. (2020). Kurum kimliğinin bir yansıması olarak kurumsal yayınlar: Koç Holding "Bizden Haberler" ve Çalık Holding "Çalık Haber" dergilerinin karşılaştırmalı analizi. İletişim Çalışmaları Dergisi, 12, 1740.

Uluçay, D. M. (2018). Üniversitelerde kurumsal imaj ölçümü. Dumlupınar Üniversitesi Sosyal Bilimler Dergisi,55, 17-36.

Van Riel, C. B.M. and Fombru, C. J. (2007). Essentials of corporate communication implementing practices for effective reputation management. Londra ve New York: Routledge.

Virvilaite, R. and Daubaraite, U. (2011). Corporate social responsibility in forming corporate image. Inzinerine Ekonomika-Engineering Economics, 22(5), 534-543.

Wood, E. (2001). Corporate Identity. A. Theaker (Ed.). The Public Relations Handbook (içinde s.95-114). Londra: Routledge.

https://www.capital.com.tr.listeler/capital-500 adresinden erişildi.

https://www.tupras.com.tr/uploads/dergi-rafineri-html/Rafine22/index.html https://kilometre.opet.com.tr/p/pdf.html 


\section{Kaynakça Bilgisi / Citation Information}

Koçer, S. ve Ölçer, N. (2021). Kurumsal iletişimde kurumsal dergilerin kullanımı üzerine bir inceleme. OPUS-Uluslararası Toplum Araştırmaları Dergisi, 18(Yönetim ve organizasyon Özel Sayısı), 1415-1447. DOI: 10.26466/opus.885254 